\title{
Effect of Red Lentil Flour Addition on Total Polyphenols Content and Antioxidant Capacity of Frozen Dough Bread
}

\author{
ADRIANA ELENA BOERIU ${ }^{1}$, CARMEN LILIANA BADARAU ${ }^{1 *}$, CRISTINA MARIA CANJA ${ }^{\mathbf{1}}$, \\ GAVRILA CALEFARIU ${ }^{2}$ \\ ${ }^{1}$ Transilvania University of Brasov, Faculty of Food and Tourism, 148 Castelului Str., 500014, Brasov, Romania \\ ${ }^{2}$ Transilvania University of Brașov, Faculty of Technological Engineering and Industrial Management, 1 Universitatii Str., \\ 500068, Brasov, Romania
}

\begin{abstract}
The fortification of frozen dough improved with addition of pulse flour - red lentil flour in various proportions (15\% and 30\%) was analyzed in order to raise the protein content, total polyphenol content (TPC) and antioxidant capacity (expressed using DPPH and CUPRAC methods) of wheat bread obtained from frozen dough. The high-protein, phenolic and flavonoid compounds potential of red lentil was considered for expanding the range of products obtained from frozen dough and physicochemical attributes (acidity, moisture porosity and ash content) were analyzed. Results showed that the bread formulated with $30 \%$ red lentil flour had the highest antioxidant capacity. The protein content showed higher values for samples with fortification, freezing treatment not affecting the content. The results denoted that enrichment of wheat dough with red lentil flour significantly increases the levels of polyphenols and the antioxidant activity of the final products. A strong increasement of phenolic compounds content was observed for the frozen samples, differences between fermented and unfermented samples and frozen and unfrozen samples varying significantly.
\end{abstract}

Keywords: red lentil flour, freezing process, total polyphenolic content, antioxidant capacity

\section{Introduction}

Bread is a popular food product that has been consumed frequently according to the most diets of nowadays living. It has been consumed for about 2,000 years being frequently varied with different ingredients according to cultural customs, geographical area, religious beliefs and health aspects.

Actual tendencies of contemporary consumption require use of ingredients with functional properties that bring an immediate effect on health and wellbeing. Lacking in fiber content, nutrients and bioactive components, wheat flour is considered lower from the nutritional point of view comparing to milk, soya bean, peas as its protein is deficient in essential amino acids such as lysine and threonine [1]. In reaction to this deficiency, there has been a great interest for value the properties of pulses, known as leguminous due to their high content of protein, fiber and antioxidants [2-5].

One of the most important pulse, that is frequently used in Mediterranean diet is lentil, providing enough amounts of essential amino acids that meet the nutritional requirements, despite its deficiency in Sulphur content as most of legumes [6,7] The high content of essential nutrients such as minerals, vitamins, complex carbohydrates and the antioxidant capacity, classifies lentil as a multivalent source, being successfully represented as a novel and representative ingredient for a series of well consumed products that fulfill daily diet, such as bread and bakery products.

Phenolic compounds reside in esculent and non-esculent fractions of vegetable material and own the ability to act as antioxidants. Their ability to counteract the oxidizing reactions that occur for lipids and proteins covers also the DNA profile. The composition of phenols resides in series of $\mathrm{OH}$ groups interconnected to the aromatic profile. The oxidative effect of phenolic compounds resides also in preventing the oxidative diseases and have been correlated to antioxidant, anti-inflammatory, antiallergic and antimicrobial diseases [8-10]. Lentil (Lens culinaris L) are dry edible seeds of plants belonging to Leguminosae family, but occidental perception is increasingly using lentil as pulse flour in

\footnotetext{
*email:carmen.badarau@unitbv.ro
} 
order to achieve sensory and nutritional properties that suits to the demands of the diets - gluten free, high fiber, vegetarian and newly vegan [11-13].

Lentils represent a valuable source of important antioxidants due to the phenolic compounds that have been analyzed by several researchers, focusing on the antioxidant profile $[14,15]$.

According to the actual task of preferences and tastes that are continuously changing, bakery products are submitted to perpetual change, aiming to ensure the nutritional demands. The modern consumer demand for freshly baked products with improved properties and immediately available, for minimal costs and facility in preparation. The socio-cultural context pushed the consumer to choose frozen products because they fulfill its expectations and fit to the actual lifestyle accomplishing more requirements in one product - novel ingredients and higher accessibility.

In this context, bread had suffered an important process of industrialization, with purpose of saving costs and diminishing time for product manufacturing.

The aim of the current study was to investigate the effect of several red lentil flour addition (15\%, $30 \%$ ) and of thermal treatments applied on the total polyphenol content, on the antioxidant activity and on a series of physicochemical parameters (acidity, ash, moisture and porosity) of bread samples.

\section{Materials and methods}

\subsection{Preparation and analysis of red lentil flour Lentil flour obtaining}

Lentil flour was obtained by milling red lentil seeds in a laboratory mill (IKA MF 10.1) by using MF 1.0 , sieve with diameter $1 \mathrm{~mm}$.

\section{Total polyphenols content}

$50 \mu \mathrm{L}$ of obtained extract methanol solution $\left(50 \mathrm{mg} / 100 \mathrm{~mL}^{-1}\right), 950 \mu \mathrm{L}$ of distilled water, $50 \mu \mathrm{L}$ of Folin-Ciocalteu reagent (Sigma-Aldrich, Darmstadt, Germany) diluted with distilled water (1:1 v/v) and $100 \mu \mathrm{L}$ of $7 \% \mathrm{Na}_{2} \mathrm{CO}_{3}$ (Chimopar, Romania) solution were added. The reaction mixture was incubated in darkness for $30 \mathrm{~min}$. and then the absorbance was measured at $750 \mathrm{~nm}$. The obtained results were expressed as quercetin equivalent (QE, Sigma-Aldrich, Darmstadt, Germany) [16].

\section{Total flavonoids content}

To $400 \mu \mathrm{L}$ of the flour extract, $40 \mu \mathrm{L}$ of $5 \% \mathrm{NaNO}_{2}$ (Chimopar), $40 \mu \mathrm{L}$ of $10 \% \mathrm{AlCl}_{3}$ (Chimopar), $400 \mu \mathrm{L}$ of $4 \% \mathrm{NaOH}$ (Chimopar) and $120 \mu \mathrm{L}$ of distilled water were added. The reaction mixture was incubated in darkness for $15 \mathrm{~min}$ and next the absorbance was measured at $430 \mathrm{~nm}$. The flavonoids content was determined based on the calibration curve for the quercetin solutions in the range of 10-500 $\mu \mathrm{M}[17]$.

\section{Antioxidant activity against DPPH• radicals}

To $1 \mathrm{~mL}$ of $100 \mu \mathrm{M}$ (DPPH) - radical solution (Sigma-Aldrich), $30 \mu \mathrm{L}$ of the extract methanol solution $\left(5 \mathrm{mg} 100 \mathrm{~mL}^{-1}\right.$ ) was added. After $30 \mathrm{~min}$ of incubation in darkness, the absorbance was measured at $515 \mathrm{~nm}$. Quercetin $(0-250 \mu \mathrm{M}$ concentration) was used for calibration and the results were expressed as $\mathrm{mg}$ of quercetin equivalent (QE) per $1 \mathrm{~g}$ of extract [18].

\section{Determination of the antioxidant activity using CUPRAC method}

To $0.25 \mathrm{~mL}$ of $1 \mathrm{mM} \mathrm{CuCl}_{2}$ (Sigma-Aldrich), $0.25 \mathrm{~mL}$ of $7.5 \mathrm{mM}$ neocuproine (Sigma-Aldrich), 0.25 $\mathrm{mL}$ of $1 \mathrm{M} \mathrm{NH}_{4} \mathrm{Ac}$ (Chimopar), $50 \mu \mathrm{L}$ of the research sample and $0.20 \mathrm{~mL}$ of distilled water were added. The mixture used for reaction was incubated for $30 \mathrm{~min}$. at room temperature in darkness. Next, the absorbance was measured at $\lambda=450 \mathrm{~nm}$ (using a blank sample as a reference). Quercetin $(0-500 \mu \mathrm{M}$ concentration) was used for calibration and the results were expressed as mg of quercetin equivalent per $1 \mathrm{~g}$ of the sample [16]. 


\subsection{Preparation of bread samples enriched with red lentil flour}

The red lentil flour obtained and analyzed in laboratory was weighted and mixed with wheat flour in different proportions. The bread formulations were carried by varying the content of added lentil flour reported to $100 \mathrm{~g}$ wheat flour (substitution of wheat flour ratios of 100:15 and 100:30) and control samples were prepared (with no addition of lentil flour and with addition of lentil flour but unfrozen), commercial baker's yeast type Saccharomyces cerevisiae (3\% reported to the added flour), iodized salt ( $2 \%$ reported to the added flour), sunflower oil (5\% flour added) and water needed to fulfill the hydration capacity of lentil flour added. The bread was obtained using the straight dough method of preparation. All the ingredients were prepared, then dosed and mixed at the speed of $250 \mathrm{rpm}$. for $15 \mathrm{~min}$ in a laboratory mixer (Tefal Wizzo, China) until a homogenous consistency and a flexible mass was obtained. Then, the dough was divided in pieces of $50 \mathrm{~g}$, modelled in round shape as bread buns, placed in stainless steel trays and then half number were frozen at $-25^{\circ} \mathrm{C}$ for $12 \mathrm{~h}$ in freezer (Liebherr GGUesf1405, Germany) and the other half were then placed for fermentation in an oven (Whirlpool Absolute Gallery AKZM, Poland) at monitored temperature of $25^{\circ} \mathrm{C}$ for $30 \mathrm{~min}$. After fermentation, the samples were frozen at $-25^{\circ} \mathrm{C}$ for $12 \mathrm{~h}$ in freezer (Liebherr GGUesf1405, Germany). The control samples were separated in two categories - one part were frozen unfermented and one part were fermented and then frozen in the same conditions as the samples with lentil flour addition. After $12 \mathrm{~h}$, the samples were baked in oven (Whirlpool Absolute Gallery AKZM, Poland) at $200^{\circ} \mathrm{C}$ for $30 \mathrm{~min}$ and then cooled at $20 \ldots 22^{\circ} \mathrm{C}$ for $2 \mathrm{~h}$ and then subjected to physical and sensory analysis.

\subsection{Analysis of bread samples}

\section{Determination of antioxidant activity of bread sample}

Sample of $5 \mathrm{~g}$ of bread was homogenized in $50 \mathrm{~mL}$ of methanol (30 s, $20000 \mathrm{rpm}$ ). The homogenate was shaken for $30 \mathrm{~min}(180 \mathrm{rpm})$ and clarified by centrifugation at $10000 \mathrm{~g}$ for $15 \mathrm{~min}$. The obtained supernatant was used to determine the total polyphenols content and antioxidant activity using DPPH and CUPRAC method (similar to the methods used for flour analysis). The antioxidant activity of bread sample was expressed as trolox equivalent (TE, Sigma-Aldrich) while the polyphenols content as gallic acid equivalent (GAE, Sigma-Aldrich) per $100 \mathrm{~g}$ of the bread.

\section{Titratable acidity (TTA)}

15 grams of sample were minced in small pieces in order to facilitate the homogenization. Then, the sample was transferred into a glass flask and $100 \mathrm{~mL}$ of distilled water were added. The mixture was mixed and shaken until a homogeneous phase was attained. Then, the titration agent was prepared (sodium hydroxide 0.1N Sigma-Aldrich, Dublin, Ireland).Three drops of indicator were added phenolphthalein $1 \%$ in alcoholic solution and the titration is started drop to drop, until the indicator turns into pink and resides for about $30 \mathrm{~s}$. The total titratable acidity is expressed as acidity degrees per $100 \mathrm{~g}$ product.

\section{Total titratable acidity $=\left[\frac{V \times 0,1}{m}\right] \times 100$ [acidity degrees $\backslash 100$ groduct $]$}

\section{Protein content}

Protein content was determined according to the Kjeldahl method following three steps mineralization, neutralisation and titration. $1 \mathrm{~g}$ of bread core was hydrolyzed with $15 \mathrm{~mL}$ concentrated sulfuric acid and two tablets of catalyst were added in a tube. The tube was placed in the heat dwelling (Kjeldahl System DK6, UDK 129 Kjeldahl Distillation Unit 2019, Velp Scientifica) at $420^{\circ} \mathrm{C}$ for $2 \mathrm{~h}$. After finishing the process, the samples were cooled for about $30 \mathrm{~min}$. After cooling, before neutralisation and titration was added distilled water. It was obtained the amount of total nitrogen and multiplied with the conversion factor 6.25 and 5.7 for bread in order to determine the total protein content of samples. 


\section{Moisture determination}

An amount of $5 \mathrm{~g}$ of bread sample were weighted on an analytical balance. A weighting vial is tared before determination and $1 / 3$ of the total volume is fulfilled with sand. Then, the bread sample is added, the vial is covered with a cap and then dried in the drying stove at $130 \pm 2^{\circ} \mathrm{C}$ for $1 \mathrm{~h}$. After that, the vial is cooled in the desiccator for $30 \mathrm{~min}$. Then, the sample is weighted and the moisture content is expressed with the following formula:

\section{Porosity determination}

$$
\text { Moisture content }=\frac{\left(T_{w}-D_{w}\right)}{T_{w}} \times 100[\%]
$$

The sample is sliced in slices of $60 \mathrm{~mm}$., and after that, with a metallic cylindrical perforator, well sharpened, a cylindrical piece is obtained. The piece is then subjected to weighting by determining the total volume of air balls for the volume, taking into account the known density and mass. It is determined the high and the diameter of the bread core cylinder. It is considered a density of $\rho=1.31 \mathrm{~g} / \mathrm{cm}^{3}$ for white wheat flour bread. The porosity is determined with the following formula:

\section{Ash content}

$$
\text { Porosity }=\frac{\left(\frac{V-m}{\rho}\right)}{V \times 100}[\%]
$$

$5 \mathrm{~g}$ of bread were weighted and then introduced in a crucible previously burned at $600^{\circ} \mathrm{C}$ and tared. The crucible was then burned on a gas burner until carbonization. Then, the used crucible was introduced in a calcination oven for $6 \mathrm{~h}$. Then, the sample was cooled in a desiccator for $30 \mathrm{~min}$ and then weighted. The ash content was estimated with the following formula, considering $\mathrm{m}_{2}$ - the mass of the crucible with ash, $\mathrm{m}_{1}$ - the mass of the crucible with sample, $\mathrm{m}_{0}$ - crucible mass, $\mathrm{U}$ - product moisture.

\subsection{Statistical analysis}

$$
\text { Ash content }=\frac{m_{2-} m_{0}}{m_{1}-m_{0}} \times 100 \times \frac{100}{100-U}[\%]
$$

Data analyses of determinations was performed by using SPSS (Statistical Package for the Social Sciences), IBM Corporation, Spss Inc., Chicago, Illinois, USA) at a significance level of $\mathrm{p}<0.05$, meaning that is retained the null hypothesis and rejected the alternative hypothesis. It was analyzed the correlation between all the variables studied and the data was analyzed using Duncan's Multiple Range Test (DMRT).

\section{Results and discussions}

\subsection{Bread samples obtained}

The samples prepared in this study and their coding (according to the percentage of lentil flour addition and thermal treatment) are presented in Table 1 . These samples were prepared in three repetitions. Figure 1 shows several images with the obtained bread samples.

Table 1. Sample coding (process and red lentil flour addition)

\begin{tabular}{|c|c|c|}
\hline Type & Coding & Proportion of lentil flour (\%) \\
\hline Control sample & PM & 0 \\
\hline Sample with 15\% lentil flour unfermented frozen & P1.1 & 15 \\
\hline Sample with 15\% lentil flour fermented frozen & P1.2 & 15 \\
\hline Sample with 15\% lentil flour unfrozen & P1.3 & 15 \\
\hline Sample with 30\% lentil flour unfermented frozen & $\mathrm{P} 2.1$ & 30 \\
\hline Sample with 30\% lentil flour fermented frozen & $\mathrm{P} 2.2$ & 30 \\
\hline Sample with 30\% lentil flour unfrozen & $\mathrm{P} 2.3$ & 30 \\
\hline
\end{tabular}




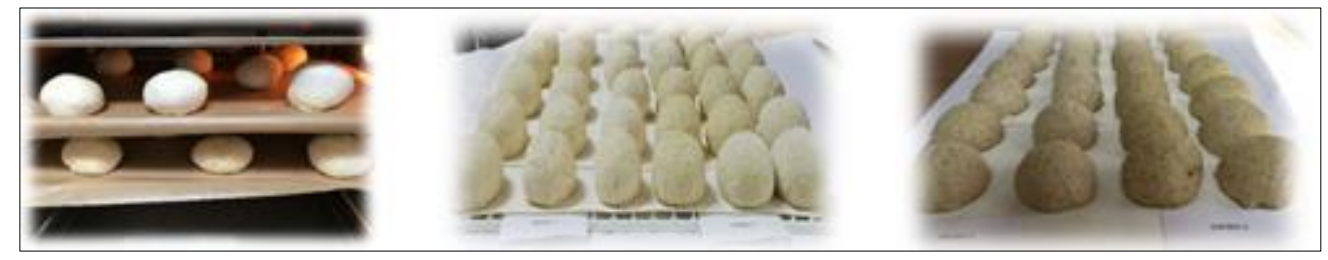

Figure 1. Bread samples: control, samples with $15 \%$ red lentil flour, samples with $30 \%$ red lentil flour

\subsection{Red lentil flour analysis}

The physical parameters of red lentil flour were determined as percent reported to dry substance. The values obtained were represented in Table 2.

Table 2. TPC, TFC, antioxidant activity and several physicochemical parameters of red lentil flour

\begin{tabular}{cccc}
\hline Parameters & Values $(\mathbf{m g ~ Q E} / \mathbf{~ 1 0 0} \mathbf{g}) *$ & Parameters & Values $(\boldsymbol{\%}) *$ \\
\hline TPC & $540.338 \pm 15.825$ & Protein $(\boldsymbol{\%})$ & $11.90 \pm 0.02$ \\
\hline TFC & $342.634 \pm 6.294$ & Ash $(\boldsymbol{\%})$ & $0.85 \pm 0.04$ \\
\hline DPPH & $512.692 \pm 3.172$ & Moisture $(\boldsymbol{\%})$ & $10.50 \pm 0.1$ \\
\hline CUPRAC & $431.108 \pm 2.641$ & Hydration capacity $(\boldsymbol{\%})$ & $0.15 \pm 0.02$ \\
\hline * Values are means of three repetitions + standard deviation & &
\end{tabular}

The analysis revealed that the red lentil flour is a good source of polyphenols and flavonoids. So, the total content of phenolic compounds was $540.338 \mathrm{mg}$ QE/ 100g, higher that the level reported in other research [19]. Beside phenolic compounds, the flavonoids contribute to health and wellbeing, bringing beneficial effects through their antioxidant activity. For the red lentil flour used in our study, the total flavonoid content was $342.634 \mathrm{mg} \mathrm{QE} / 100 \mathrm{~g}$. The total antioxidant capacity was also determined using two methods (DPPH and CUPRAC) and the obtained values (512.692 mg QE/100g for DPPH, respectively $431.108 \mathrm{mg}$ QE/ 100g, for CUPRAC method) revealed a good antioxidant potential of this lentil product. Moreover, this flour is a good source of carbohydrates, proteins and dietary fibers. According to [19] the obtained results were similar to those reported. Protein content was the highest comparing to the values for the other parameters, fact that supports the high protein potential of lentils.

\subsection{Protein content, TPC and antioxidant activity of bread samples enriched with red lentil flour}

Samples containing red lentil flour treated by freezing treatment showed higher protein content comparing to blank sample, with no addition of red lentil flour. The samples treated by freezing showed lower results comparing to samples unfrozen, sample with $30 \%$ addition of lentil flour unfrozen showing the higher results - 14.9\%. Freezing treatment relieved decreased values, fermented frozen samples presenting higher values comparing to unfermented frozen samples. Sample P1.2 and P2.2 had 12.3\% and $14.5 \%$ protein content, higher than unfermented. This fact is caused by fermentation process, protein level increasing after fermentation. Unfermented samples P1.1 and P1.3 showed decreased values 12.2\% and $14.0 \%$. The most significant development was observed for the addition of $30 \%$ of lentil flour, protein content increasing with about $0.5 \%$ for fermented samples. The differences between thermal treated samples and unfrozen samples were slightly significant, fermenting process affecting protein content being considered also by [20].

As shown in Table 3, a significant increase was observed in total phenolic compounds for the frozen samples, differences between fermented and unfermented samples and frozen and unfrozen samples being obvious. The highest increase, was observed for samples unfrozen 49.89 [mg QE/ $100 \mathrm{~g}$ ] and 109.19 [mg QE/ 100g]. Also, the fermenting process lead to substantial increase of total phenolic compounds in case of fermented frozen samples, comparing to unfermented frozen alternative, the aspect being observed in case of both types of addition. This fact was also observed for rice bran [21]. 
Table 3. Samples assessment of TPC and antioxidant capacity

\begin{tabular}{c|c|c|c|c|}
\hline $\begin{array}{c}\text { Sample } \\
\text { coding }\end{array}$ & Protein content \% & $\begin{array}{c}\text { TPC } \\
\text { [mg GAE/ 100g] }\end{array}$ & $\begin{array}{c}\text { DPPH } \\
\text { [mg trolox/ 100g] }\end{array}$ & $\begin{array}{c}\text { CUPRAC } \\
\text { [mg trolox/ 100g] }\end{array}$ \\
\hline PM & $11.8 \pm 1.000(f)$ & $19.47 \pm 1.000(f)$ & $21.26 \pm 4.902$ & $31.01 \pm 1.0009(f)$ \\
\hline P1.1 & $12.2 \pm 0.375(e)$ & $34.83 \pm 1.000(e)$ & $31.38 \pm 5.592$ & $41.33 \pm 1.000(e)$ \\
\hline P1.2 & $12.3 \pm 0.375(e)$ & $43.60 \pm 0.111(d)$ & $32.54 \pm 5.746$ & $50.26 \pm 0.495(d)$ \\
\hline P1.3 & $12.7 \pm 1.000(d)$ & $49.89 \pm 0.111(c d)$ & $50.19 \pm 0.932$ & $51.18 \pm 0.495(d)$ \\
\hline P2.1 & $14.0 \pm 1.000(c)$ & $57.12 \pm 0.710(c)$ & $56.33 \pm 1.094$ & $73.20 \pm 1.000(c)$ \\
\hline P2.2 & $14.5 \pm 1.000(b)$ & $75.87 \pm 1.000(b)$ & $74.16 \pm 0.968$ & $93.26 \pm 1.000(b)$ \\
\hline P2.3 & $14.9 \pm 1.000(a)$ & $109.19 \pm 1.000(a)$ & $110.21 \pm 0.774$ & $135.61 \pm 1.000(a)$ \\
\hline
\end{tabular}

*The values represent the means and standard deviation of the mean $\left(x^{-} \pm S D\right)$ Means values with the same lower case are not statistically significant according to Duncan test.

The antioxidant reaction of lentil flour was validated with DPPH assay. The greatest value of the total antioxidant activity was noted for sample with the higher addition of red lentil flour - $30 \%$, fact that supports the conceptualization that addition of lentil flour, improves the antioxidant content of product. Freezing treatment slightly decreases the values obtained for total antioxidant activity, fermented and unfermented samples showing lower values comparing to unfrozen samples. The lowest antioxidant activity was observed for samples with $15 \%$ addition of red lentil flour and thermal treatment, highlighting that freezing decreases the antioxidant activity. The DPPH radical activity had the highest effect on fermented samples, the scavenge activity reaching a value of $74.16 \mathrm{mg}$ QE/ $100 \mathrm{~g}$ for sample $\mathrm{P} 2$.2. For unfrozen samples, the antioxidant activity was almost double with the concentration of lentil flour added - $50.19 \mathrm{mg} \mathrm{QE} / 100 \mathrm{~g}$ for $15 \%$ lentil flour and $110.21 \mathrm{mg} \mathrm{QE} / 100 \mathrm{~g}$ for $30 \%$ lentil flour.
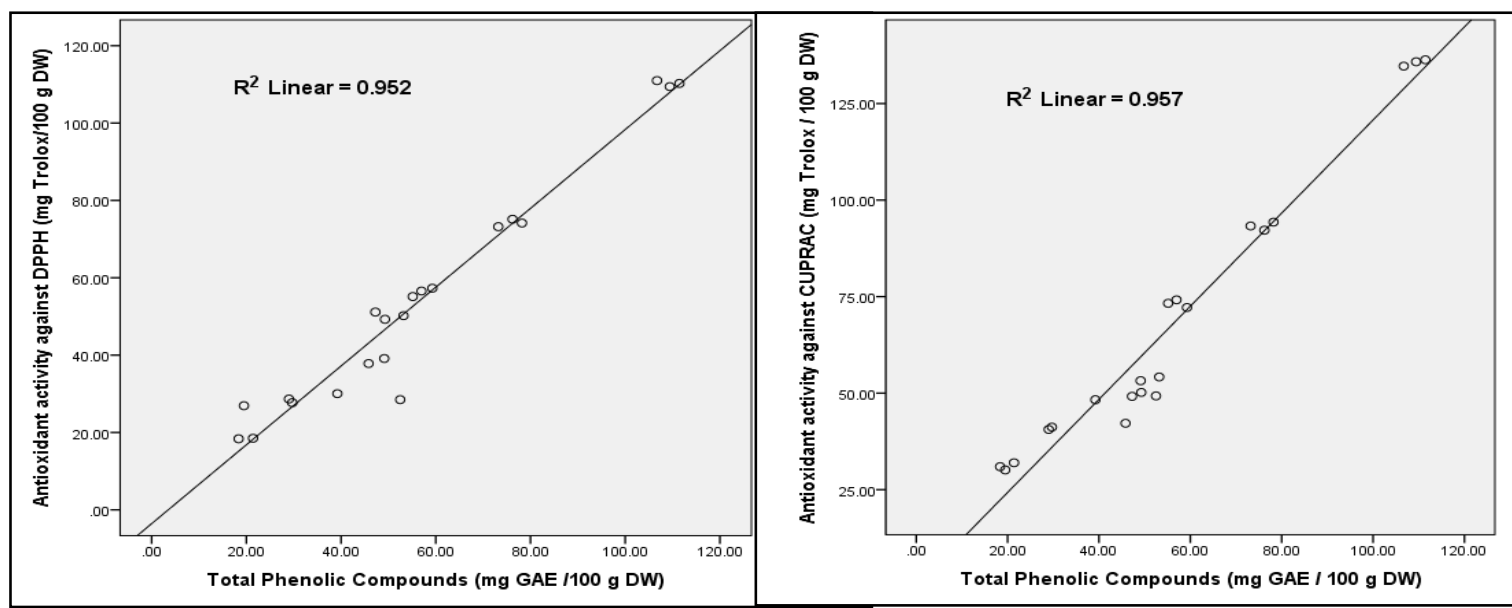

Figure 2. Correlations between the antioxidant capacity (estimated by DPPH and CUPRAC assay) and total polyphenolic content of the bread samples. Abbreviations: DPPH=2, 2-diphenyl-1picrylhydrazyl; TPC $=$ total polyphenol content; GAE= gallic acid equivalent;

$\mathrm{QE}=$ quercetin equivalent

The CUPRAC assay also confirms that the antioxidant activity of samples increased according to the amount of lentil flour added, the product maintaining antioxidant activity with thermal treatment. The most intense antioxidant activity was observed for unfrozen samples, but samples subjected to frozen treatment and fermentation showed also antioxidant activity. This method revealed an insignificant difference between frozen fermented sample and unfrozen sample, for an addition of $15 \%$ lentil flour, in case of samples P1.2 and P1.3 - 50.26 mg QE/ 100g and 51.18 mg QE/ 100g.

As seeing in Figure 2, there were a significantly correlation between the total content of polyphenol and the antioxidant capacity of the samples (determined by both methods). So, the level of TPC had a strong effect on the antioxidant capacity of the bread enriched with red lentil flour. 


\subsection{Physicochemical parameters of the bread samples}

An analysis of several physicochemical parameters was developed after $24 \mathrm{~h}$, core acidity, moisture content, porosity and ash content revealing values that were recorded in Table 4.

The degree of acidity is an important parameter in evaluating several attributes of product - quality of gluten, yeast activity and microbiological state of product. For the samples with red lentil flour, the titratable acidity increased over thermal treatment applied, the highest levels of acidity were found in the unfrozen samples - $2.3 \%$ for unfrozen sample with $30 \%$ lentil flour. The highest value was obtained for unfermented sample with $30 \%$ red lentil flour $-2.9 \%$. This fact is influenced by the acidic properties of lentil, attribute mentioned by different researchers.

Table 4. Physicochemical parameters of bread samples (evaluated at $24 \mathrm{~h}$ )

\begin{tabular}{|c|c|c|c|c|}
\hline \multirow{2}{*}{$\begin{array}{l}\text { Sample } \\
\text { coding }\end{array}$} & \multicolumn{4}{|c|}{ Parameters* } \\
\hline & Acidity \% & Moisture \% & Porosity \% & Ash \% \\
\hline $\mathrm{PM}$ & $2.8 \pm 0.100(c d)$ & $44.2 \pm 0.100(a b)$ & $85.3 \pm 3.000(a b)$ & $1.63 \pm 0.200(b)$ \\
\hline P1.1 & $2.8 \pm 0.200(c d)$ & $43.3 \pm 0.200(a b c)$ & $75.3 \pm 2.500(c d e)$ & $1.86 \pm 0.100(b)$ \\
\hline $\mathrm{P} 1.2$ & $2.5 \pm 0.200($ def $)$ & $40.8 \pm 0.130$ (efg) & $77 \pm 1.500(c d)$ & $1.85 \pm 0.100(b)$ \\
\hline $\mathrm{P} 1.3$ & $2.5 \pm 0.150(\mathrm{def})$ & $44 \pm 0.200(a b)$ & $78.6 \pm 1.700(c)$ & $1.83 \pm 0.150(b)$ \\
\hline $\mathrm{P} 2.1$ & $2.9 \pm 0.150(b c)$ & $40.3 \pm 0.100(f g)$ & $71 \pm 2.000(\mathrm{hi})$ & $2.21 \pm 0.150(b)$ \\
\hline $\mathrm{P} 2.2$ & $2.5 \pm 0.250($ def $)$ & $41 \pm 0.150(e f g)$ & $72.1 \pm 1.500(g-i)$ & $2.20 \pm 0.200(b)$ \\
\hline $\mathrm{P} 2.3$ & $2.3 \pm 0.200(f g)$ & $43.1 \pm 0.200(a b c d)$ & $71 \pm 3.000(h i)$ & $2.30 \pm 0.150(b)$ \\
\hline
\end{tabular}

*The values represent the means and standard deviation of the mean $\left(x^{-} \pm S D\right)$ Means values with the same lower case are not statistically significant according to Duncan test.

The moisture content significantly differ between breads obtained with different thermal treatments and the values differ according to applied treatment. The highest value was observed for sample with $15 \%$ red lentil flour unfrozen - $44 \%$, similar to the value of blank sample with no addition of lentil flour. The samples stored under freezing conditions showed a lower rate of moisture varying between $40.3 \%$ for unfermented frozen sample with $30 \%$ red lentil flour and $43.3 \%$ for samples with $15 \%$ red lentil flour. Lentil flour had high capacity of absorption and retaining of water more than wheat flour, aspect denoted by [4], but due to the thermal treatment applied, water turns into crystals and is lost through freezing.

The porosity of the bread was determined, the most porous bread being the sample with $15 \%$ red lentil flour with $78.6 \%$ unfrozen. Similar values were obtained for fermented samples - P1.2 and P2.2 (77 and $72.1 \%$ ), concluding that fermentation helps to improve the porosity of the final product. Decreased values of the porosity comparing to the blank sample were caused by the different proportion of red lentil flour added, unfrozen sample with the higher addition of red lentil flour having the most negative effect towards porosity.

Another parameter analyzed was the ash content, and it can be observed how the values increase as the proportion of red lentil flour added increases. The ash content of lentil reflects in the total ash content of final product. Values ranged from 1.86 to $2.30 \%$. Red lentil flour gave significantly higher values of ash content, freezing process leading to higher values, comparing to unfrozen samples $-1.86 \%$ for P1.1 to $1.83 \%$ for P1.3, similar results were reported for the addition of $30 \%$ lentil flour.

The daily consumption of bread is estimated to make up approximately $70 \%$ of the total cereal consumption. This means that bread and bakery goods are considered to be the best products to fortify, according to [22]. This study investigates whether enrichment of wheat dough with red lentil flour enhances the total antioxidant activity of the final product. For the fortified bread samples, there have been determined the total polyphenol content using Folin-Ciocalteu's method, and the antioxidant properties using the DPPH and CUPRAC methods. Our research has shown that enrichment of wheat dough with red lentil flour significantly increases the levels of polyphenols and the antioxidant activity of final product. We observed a closely correlation between the red lentil flour percentage (dose) and 


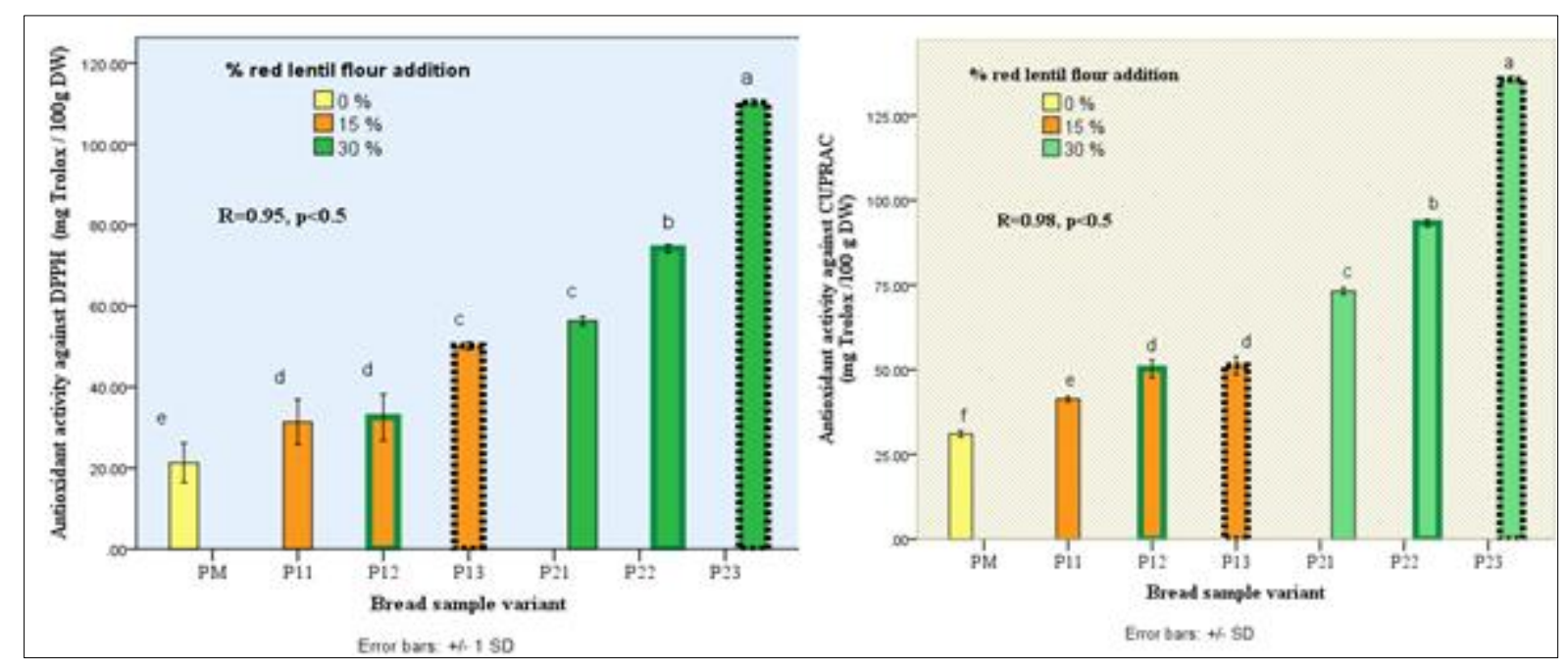

Figure 3. Antioxidant activity of bread enriched with red lentil flour. A - antioxidant activity against DPPH radicals, expressed as a Trolox equivalent. B - antioxidant activity assayed with CUPRAC method, expressed as a Trolox equivalent. The bars and error bars represent the means and standard deviation of the mean $\left(\mathrm{x}^{-} \pm \mathrm{SD}\right)$. Mean values with the same lower case are not statistically significant according to Duncan test

antioxidant activity of enriched bread ( $\mathrm{p}<0.05$ ). Antioxidant activity and phenolic compounds content in bread increased with increasing lentil flour dose. For instance, the enrichment of dough with $30 \%$ of red lentil flour caused an increase in total phenolic content in bread by three-times and antioxidant activity by three-times measured by the CUPRAC method (Figure 3 ).

Peng et al. [23] observed that the addition of a commercial grape seed extract $(0.3 \mathrm{~g}, 0.6 \mathrm{~g}$ and $1 \mathrm{~g})$ to $500 \mathrm{~g}$ of the flour to be used to make bread also enhanced the antioxidant properties of the final product. They noticed, however, that the enhancement was not proportional to the extract dose used. The authors supposed that their extract was characterized by low stability for the baking conditions. Wang, Zhou, and Isabelle [24] evaluated the quality of bread enriched with green tea extract at doses of $1.5 \mathrm{~g}$ and $5 \mathrm{~g}$ per $1 \mathrm{~kg}$ of the flour to be used to make bread. Their research showed that the addition of a green tea extract improves significantly the general quality of bread, but also significantly affects the sensory characteristics of bread, significantly, its color. In our research, we also noticed a positive effect of the addition of red lentil flour on the bread color. As in our study (Figure 1) since the green tea extract is characterized by a light brown color, bread enriched with it becomes yellow to brown in color, depending on the dose used. Piechowiak et al. [25] also noticed the antioxidant properties revealed of yellow onion skin and examined their potential in functional bread products.

\section{Conclusions}

Bread with high amounts of antioxidants can become a preferred product for consumers due to their impact on human health and wellbeing, and novel technologies, such as freezing and red lentil flour addition, can create the opportunity to consume freshly and more healthy products.

The red lentil flour used in this study was characterized by high level of protein content and antioxidant activity induced by high total content of polyphenol and flavonoid compounds. Moreover, total antioxidant activity of bread enriched with red lentil flour was closely correlated with the enrichment dose. The highest antioxidant power was observed for unfrozen samples, but samples with frozen treatment and fermentation showed also suitable antioxidant activity.

The presented research gives the opportunity to conduct further research on the effect of this addition and other additions on the sensory quality of bread enriched with the extract as well as rheological properties of the dough. 


\section{References}

1. DEWETTINCK, K., VAN BOCKSTAELE, F., KUHNE, B., VAN DE WALLE, D., COURTENS, T.M., GELLYNCK, X., Nutritional value of bread: Influence of processing, food interaction and consumer perception, Rev. J. Cereal Sci., 48, 2008, 243-257.

2. OFUYA, Z.M., AKHIDUE, V., The Role of Pulses in Human Nutrition: A Review, J. Appl. Sci. Environ. Mgt., 9, 2005, 99-104.

3. ASIF, M., ROONEY, L.W., ALI, R., RIAZ, M.N., Application and opportunities of pulses in food system: A review, Crit. Rev. Food Sci. Nutr., 53, 2013, 1168-1179.

4. BOYE, J., ZARE, F., PLETCH, A., Pulse proteins: Processing, characterization, functional properties and applications in food and feed, Food Res. Int., 43, 2010, 414-431.

5. BORA, P.S., Functional properties of native and succinylated lentil (Lens culinaris) globulins, Food Chem., 77, 2002, 171-176.

6. SOZER, N., HOLOPAINEN-MANTILA, U., POUTANEN, K., Traditional and New Food Uses of Pulses, Cereal Chem., 94(1), 2016, 66-73.

7. BAMDAD, F., DOKHANI, S., KERAMAT, J., Functional Assessment and Subunit Constitution of Lentil (Lens culinaris) Proteins during Germination, Int. J. Agric. Biol., 11(6), 2009, 690-694.

8. TAN, B.L., NORHAIZAN, M.E., LIEW, W-P-P., RAHMAN, H.S., Antioxidant and Oxidative Stress: A Mutual Interplay in Age-Related Diseases, Front. Pharmcol., 9, 2018, 1-28.

9. PHAM-HUY, L.A., HE, H., PHAM-HUY, C., Free Radicals, Antioxidants in Disease and Health, Int. J. Biomed Sci., 4(2), 2008, 89-96.

10. HU, F.B., Plant-based foods and prevention of cardiovascular disease: An overview., Am. J. Clin. Nutr., 78(3), 2003, 544-551.

11. JOHARI, A., ARORA, S., POTALIYA, M., KAWATRA, A., Role of lentil (Lens culinaris L.) in human health and nutrition., Ann. Agri Bio Res., 20, 2015, 291-294.

12. JOSHI, M., TIMILSENA, Y., ADHIKARI, B., Global production, processing and utilization of lentil: A review, J. Integr. Agric., 16, 2017, 2898-2913.

13. AIDER, M., SIROIS-GOSSELIN, M., BOYE, J., Pea, Lentil and Chickpea Protein Application in Bread Making, J. Food Res., 1, 2012, 160-173

14. ZOU, Y., CHANG, S.K.C., GU, Y., QIAN, S.Y., Antioxidant activity and phenolic compositions of lentil (Lens culinaris var. Morton) extract and its fractions, J. Agric. Food Chem., 59(6), 2011, 22682276.

15. ZHANGA, B., PENGA. H., DENGA, Z., TSAOB, R., Phytochemicals of lentil (Lens culinaris) and their antioxidant and anti-inflammatory effects, J. Food Bioact., 1, 2018, 93-103.

16. OZYURT, D., DEMIRATA, B., APAK, R., Determination of total antioxidant capacity by a new spectrofluorometric method based on $\mathrm{Ce}$ (IV) reduction: $\mathrm{Ce}$ (III) fluorescence probe for CERAC assay, J. Flouresc., 21, 2011, 2069-2076.

17. BENITEZ, V., MOLLA, E., MARTIN-CABREJAS, M., AGUILERA, Y., ANDREU, F., COOLS, K., LOPEZ-ANDREU, F., COOLS, K., TERRY, L.A., ESTEBAN, R.M., Characterization of industrial onion wastes (Allium cepa L.): Dietary fibre and bioactive compounds, Plant Foods Hum. Nutr., 66, 2011, 48-57.

18. AK, T., GULCIN, I., Antioxidant and radical scavenging properties of curcumin, Chem. Biol. Interact., 174(1), 2008, 27-37.

19. YEPES, O.O., DI GIORGIO, L., GOYANES, S., MAURI, A., FAMA, L., Influence of process (extrusion/thermo-compression, casting) and lentil protein content on physicochemical properties of starch films, Carbohydr. Polym., 208, 2019, 221-231.

20. CABUK, B., NOSWORTHY, M.G., STONE, A.K., KORBER, D.R., TANAKA, T., HOUSE, J.D., NICKERSON, M.T., Effect of Fermentation on the Protein Digestibility and Levels of Non-Nutritive Compounds of Pea Protein Concentrate, Food Technol. Biol., 56(2), 2018, 257-264. 
21. NISA, K., ROSYIDA, V.T., NURHAYATI, S., INDRIANINGSIH, A.W., DARSIH, C., APRIYANA, W., IOP Conference Series: Earth and Environmental Science, Tangerang, Indonesia, 12 November 2018, p. 020041.

22. GAWLIK-DZIKI, U., KASZUKA, K., PIWOWARCZYK, K., SWIECA, M., DIZKI, D., CZYZ, J., Onion skin- Raw material for the production of supplement that enhances the health beneficial properties of wheat bread, Food Res. Inc., 73, 2015, 97-106.

23. PENG, X., MA, J., CHENG, K., JIANG, Y., FENG, C., WANG, M., The effects of grape seed extract fortification on the antioxidant activity and quality attributes of bread, Food Chem., 119, 2010, 49-53.

24. WANG, R., ZHOU, W., ISABELLE, M., Comparison study of the effect of green tea extract (GTE) on the quality of bread by instrumental analysis and sensory evaluation, Food Res. Int., 40, 2007, 470479.

25. PIECHOWIAK, T., GRZELAK-BLASZCZYK, K., BONIKOWSKI, R., BALAWEJDER, M., Optimization of extraction process of antioxidant compounds from yellow onion skin and their use in functional bread production, LWT - Food Sci. Technol., 117, 2020, 108614.

$\overline{\text { Manuscript received: } 7.05 .2020}$ 